\title{
PERFORMANCE EVALUATION OF LOW-HEAD MICROIRRIGATION SYSTEMS IN MAIZE FIELDS \\ Khedr $^{*}$ A. F., Rashad* M. A., EIMasry ${ }^{*}$ G. M., \\ El-Sayed ${ }^{*}$ A. S. and Hegazi*** M. M.
}

\begin{abstract}
The effect of the emitter type and lateral length of low-head microirrigation systems in maize fields were determined on discharge uniformity, water use efficiency (WUE) and cost analyses. Five different

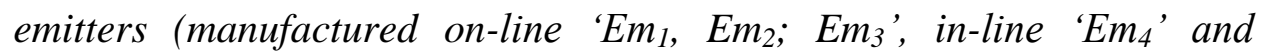
microtube 'Em ${ }_{5}$ ') were evaluated with different lateral lengths (15, 20, 25 and $30 \mathrm{~m}$ ) at operating pressure of $50 \mathrm{kPa}$. The results indicated that the coefficient of uniformity $(C U)$ decreased with increasing lateral length. The WUE as well as return of water unit (RWU) increased by increasing the uniformity. Em 4 was the highest values of yield consequently WUE and RWU, but Em 5 was the highest net seasonal income (NSI) and BC ratio, due to it has a lowest total cost. The cost analysis take into account the effect of inflation rate (Inf.) increasing by 5 or 10\%. NSI and RWU were increased by the same ratio of Inf. increasing, but BC ratio remain in the same values.
\end{abstract}

Keywords: Low-head, Microirrigation, Uniformity, Water use efficiency, Cost analyses.

\section{INTRODUCTION}

7 me main goal of the irrigation process is to achieve optimal agricultural production and maximum economic return (Merriam and Keller, 1978). Among all irrigation methods, microirrigation is a very efficient method of applying water and nutrients to crops. Microirrigation has a slow rate of water application at discrete locations with operating pressure about $10 \mathrm{~m}$ (Ngigi, 2008). The success of microirrigation is possible if the system is correctly designed with filtration unit. In general, the variable costs are related to the amount of water pumped. The fixed costs will occur regardless of amount of water used and will generally be the depreciation and interest costs based upon the amount of investment (Charles et al., 1999).

\footnotetext{
"Assistant lecturer, Assistant Prof., Associate Prof. and Prof. of Agric. Eng. Dept., Fac. Agric., Suez Canal Univ. ${ }^{* *}$ Prof. of Agric. Eng. Dept., Fac. Agric., Ain Shams Univ.
} 
Uniformity is an important parameter in the design and evaluating of microirrigation systems (Li et al., 2012). In Egypt, the new reclaimed areas must be use modern irrigation systems; since the traditional surface irrigation has low water use efficiency (Ragab and Prudhomme, 2002). Most of the Egyptian farmers who are living in the new reclaimed areas are small holder and facing poverty. Low head microirrigation systems (less than $10 \mathrm{~m}$ ) with short lateral lengths were recently introduced depending on unfiltered water (Ngigi, 2008). This system is greatly affected by pressure distribution inside a lateral or manifold as a result of the friction and pipe laying slope.

Maize (Zea mays L.) is considered one of the most important cereal crops in Egypt after wheat and rice. The cultivated maize area reached about 1.99 million feddans yearly with productivity about 6.84 million ton of grains (FAO, 2014). Therefore, microirrigation systems could be suggested for maize cultivation, the crop always planted in the overlap of wetting pattern zones. The wetting volume is affected by some factors, including emitter discharge rate, water application, emitter spacing and various soil texture (Shan et al., 2011). El-Sayed et al. (1994) studied two drip irrigation regimes under conditions of old lands in Egypt. The first regime is one lateral per one row of maize while the second regime is one lateral per two rows of maize. They found that the first irrigation regime is more efficient and reliable, in the soil profile compared to the second one, where the obtained grain yield was 4220 and $2980 \mathrm{~kg} / \mathrm{fed}$ with water use efficiency of 1.20 and $0.90 \mathrm{~kg} / \mathrm{m}^{3}$ for the first and second irrigation regimes, respectively.

The main objective of this work was to determine the effect of different emitters and lateral lengths on discharge uniformity, water use efficiency and economic feasibility of the low-head microirrigation systems in maize field.

\section{MATERIALS AND METHODS}

\section{Laboratory Experiment}

The experimental work of the present study was conducted at the Hydraulic Laboratory and the Farm of Faculty of Agriculture, Suez Canal University, Ismailia. The laboratory hydraulic experiment of subunit was 
carried out to determine the highest discharge uniformity and the optimum length of lateral. Five emitters were tested in these subunits with four lateral lengths $(15,20,25$ and $30 \mathrm{~m})$ and operating pressure of 50 $\mathrm{kPa}$.

Under different operating pressure heads $h_{i}(\mathrm{~m})$, the emitter flow rate $q$ $(\ell / \mathrm{h})$ and the coefficient of variation $\left(C_{v}\right)$ of every emitter tested in this study were estimated and classified as unacceptable $(>0.15)$, poor $(0.11$ to 0.15$)$, marginal (0.07 to 0.11$)$, average ( 0.05 to 0.07$)$, excellent $(<0.05)$ according to the following two equations emphasized by ASABE EP 405.1 (2008):

$$
\begin{aligned}
& q=k h_{i}^{x} \\
& C_{v}=\frac{S}{\bar{X}}
\end{aligned}
$$

where, $k$ is a dimensionless constant of proportionality that characterizes each emitter, $x$ is a dimensionless emitter discharge exponent that is characterized by the flow regime and $\bar{X} ; S$ are the mean discharge and standard deviation of emitters.

Because, the coefficient of uniformity $(C U)$ is a better way of expressing the variation in discharge along lateral lines, it was classified as below 60 $\%$, from 60 to $70 \%, 70$ to from $80 \%$, from 80 to $90 \%$; above $90 \%$ is referred to as low, poor, fair, good; excellent uniformity, respectively, and calculated using the following equation (Christiansen, 1942 and ASAE EP 458.0, 1999):

$$
C U=100\left(1-\frac{\sum_{i=1}^{i=n}\left|q_{i}-\bar{q}\right|}{n \bar{q}}\right)
$$

where, $\sum_{i=1}^{i=n}\left|q_{i}-\bar{q}\right|$ is the summation of absolute values of deviation from the means of emitter discharge, $q_{i}$ is the individual discharge of each emitter $(\ell / \mathrm{h}), \bar{q}$ is the mean of emitter discharge $(\ell / \mathrm{h})$ and $n$ is the number of collectors measured. Combined analysis of variance (ANOVA) was estimated using CoStat software version 6.311 according to Steel and Torrie (1984). The significance of differences was determined among the examined emitters with different lateral length. 


\section{Field Experiment}

Studying the effect of different emitters on maize yield and water use efficiency will help in estimating the water saving as well as cost analysis. The field experimental work was conducted under Egyptian conditions at the Research Farm of Faculty of Agriculture, Suez Canal University, Ismailia, Egypt. As shown in Figure (1), the setup of field experiment consists of water source from Ismailia canal (branched from Nile River), pump unit of the farm, main line with outer diameter $(O D)$ of $75 \mathrm{~mm}$, submain line having $63 \mathrm{~mm}$ out diameter, manifold lines with $50 \mathrm{~mm}$ branched from the submain, control valves, flow meter, pressure gauge ( 0 - $250 \mathrm{kPa}$ ) with scale accuracy of $10 \mathrm{kPa}$ distributed through the submain unit to control the flow and pressure. Lateral lines made from polyethylene $(P E)$ with internal diameter $(I D)$ of $13.6 \mathrm{~mm}$ were

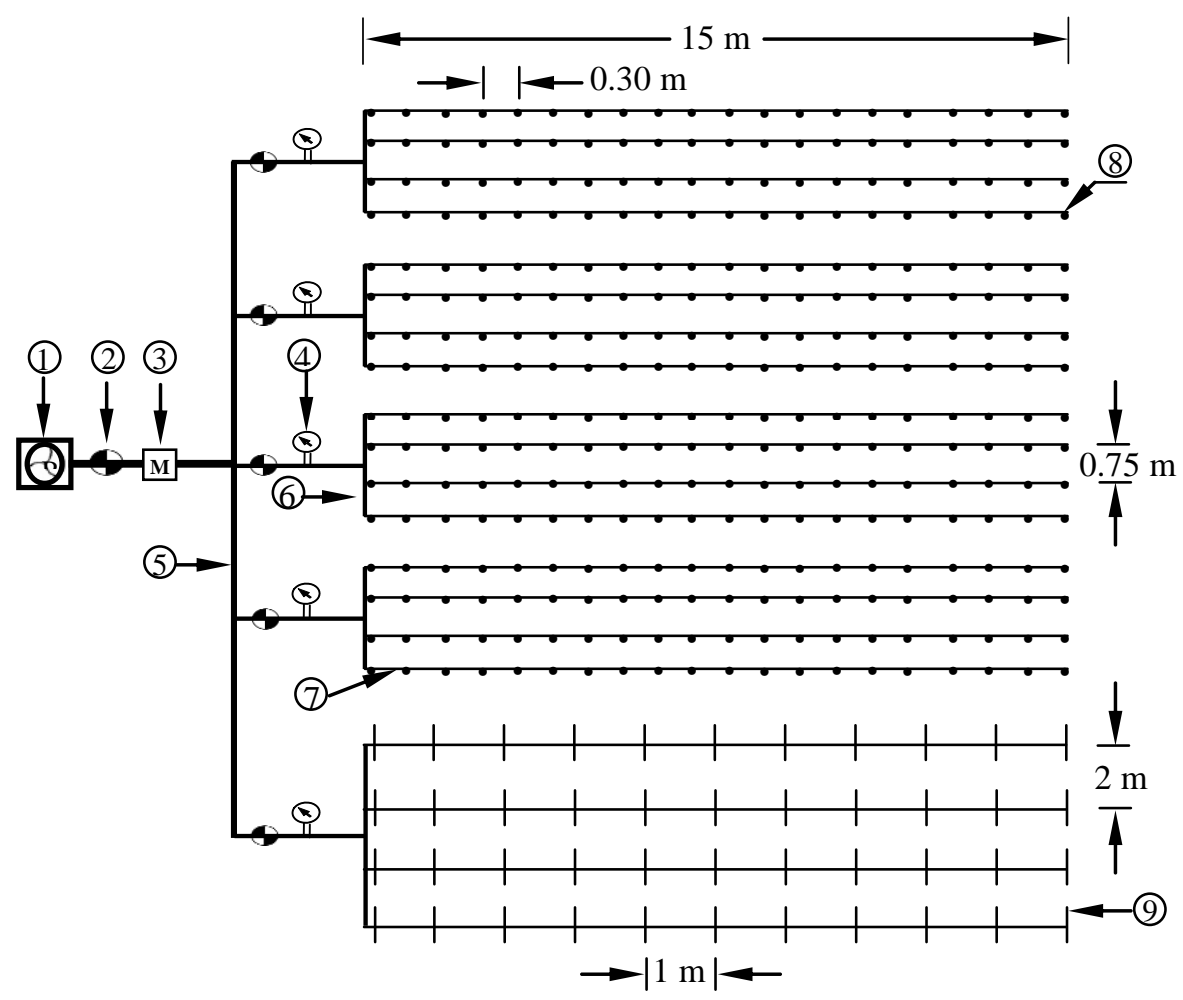

1- Water pump 2- Valve 3- Water meter 4- Pressure gauge 5- Submain line 6- Manifold line 7- Lateral line 8- Emitter 9 - Microtube

Figure (1): Schematic diagram of the field experiment. 
connected with manifold line. Five emitters from the local market were tested under constant pressure of $50 \mathrm{kPa}$ with lateral length of $15 \mathrm{~m}$. As shown in Table (1), the tested emitters were divided into three categories: on-line manufactured $\left(E m_{1}, E m_{2}, E m_{3}\right)$ where $E m_{1}$ and $E m_{2}$ were global manufacturer but $\mathrm{Em}_{3}$ was local manufacturer, in-line manufactured $\left(E m_{4}\right)$ and microtube $\left(E m_{5}\right)$. The internal distance between laterals was 75 $\mathrm{cm}$ with emitter spacing of $30 \mathrm{~cm}$. Microtube $\left(E m_{5}\right)$ has a length of $50 \mathrm{~cm}$ and $3.80 \mathrm{~mm}$ (ID) at a spacing of $100 \mathrm{~cm}$ distributed by head to head system on the laterals which designed at internal distance of $200 \mathrm{~cm}$.

Table (1): Emitter types symbols and nominal discharge at $100 \mathrm{kPa}$.

\begin{tabular}{|c|c|c|}
\hline Emitter types (trademark) & Symbol & Nominal discharge " $\ell / \mathrm{h} "$ \\
\hline Eden & $E m_{1}$ & $4.0 \ell / \mathrm{h}$ \\
\hline Euro-key & $E m_{2}$ & $4.0 \mathrm{l} / \mathrm{h}$ \\
\hline Metallic & $\mathrm{Em}_{3}$ & $4.0 \mathrm{\ell} / \mathrm{h}$ \\
\hline $\mathrm{GR}^{*}$ & $\mathrm{Em}_{4}$ & $4.0 \ell / \mathrm{h}$ \\
\hline Microtube $(3.80 \mathrm{~mm} I D)$ & $E m_{5}$ & Unknown \\
\hline
\end{tabular}

The irrigations system was installed in the maize field located at $13 \mathrm{~m}$ elevation above sea level, Latitude angle of $30^{\circ} 58^{\prime} \mathrm{N}$ and Longitude angle of $32^{\circ} 23^{\prime}$ E. The maize crop (Zea mays $L$.) was a yellow variety of Three Way Cross 352 (T.W.C. 352) planted on $1^{\text {st }}$ May to $28^{\text {th }}$ August during the summer season of 2012. This crop was cultivated in a sandy soil with about $25-30 \mathrm{~cm}$ distances between plants. Full water requirements and recommendation of Egyptian Agriculture Ministry for cultivation and fertilization practices were applied. Soil samples were collected to determine some physical and chemical characteristics of soil depths from 0 to $60 \mathrm{~cm}$ at root depth according to Black (1969). The analysis showed that at this depth the soil is considered to be homogeneous layer (Table (2)).

\section{Water Saving}

The daily evapotranspiration $\left(E T_{c}\right)$ through agriculture season was calculated using CROPWAT software version 8.0 based on PenmanMonteith equation which recommended by FAO (Allen et al., 2011). Application efficiency as $85 \%$ was constant for this study. 
Table (2): Some physical characteristics of the experimental field.

\begin{tabular}{|c|c|c|c|c|c|c|c|c|c|}
\hline \multirow{3}{*}{ Depth $(\mathrm{cm})$} & \multicolumn{4}{|c|}{ Particle size distribution } & \multirow{3}{*}{$\begin{array}{c}\text { Texture } \\
\text { Class }\end{array}$} & \multicolumn{3}{|c|}{ Soil moisture content } & \multirow{3}{*}{$\begin{array}{l}D B D \\
\mathrm{~g} / \mathrm{cm}^{3}\end{array}$} \\
\hline & \multicolumn{2}{|c|}{ Sand $(\%)$} & \multirow{2}{*}{$\begin{array}{l}\text { Silt } \\
(\%)\end{array}$} & \multirow{2}{*}{$\begin{array}{c}\text { Clay } \\
(\%)\end{array}$} & & \multirow{2}{*}{$\begin{array}{l}F C \\
(\%)\end{array}$} & \multirow{2}{*}{$\begin{array}{c}P W P \\
(\%)\end{array}$} & \multirow{2}{*}{$\begin{array}{l}A W \\
(\%)\end{array}$} & \\
\hline & Coarse & Fine & & & & & & & \\
\hline $0-30$ & 80.1 & 15.1 & 1.8 & 3.0 & Sandy & 9.10 & 1.79 & 7.31 & 1.63 \\
\hline $30-60$ & 80.3 & 15.2 & 1.7 & 2.8 & Sandy & 9.00 & 1.80 & 7.20 & 1.61 \\
\hline
\end{tabular}

$F C$ : Field capacity (- $0.1 \mathrm{~atm}), P W P$ : Permanent wilting point (- $15 \mathrm{~atm})$,

$A W$ : Available water, $D B D$ : Dry bulk density.

The irrigation interval can be determined by identifying the maximum water that can be stored in the soil and the consumptive use of crops as follows (Keller and Karmeli, 1974; Keller and Bliesner, 1990).

$$
D_{n}=\frac{F C-P W P}{100} \times p \times Z_{r} \times D B D
$$

where, $D_{n}$ is the maximum net depth of each irrigation application $(\mathrm{mm})$, $F C$ is field capacity (\%), $P W P$ is permanent wilting point (\%), $p$ is fraction of available moisture depletion allowed, $Z_{r}$ is the root depth $(\mathrm{mm})$ and $D B D$ is relative density of soil $\left(\mathrm{g} / \mathrm{cm}^{3}\right)$.

The irrigation interval $(F)$ in days depends on the rate at which water is consumed by the plants and the depth of irrigation applied by each cycle. To obtain the irrigation interval based on water stored in root zone the following two relations were used (Keller and Karmeli, 1974):

$$
\begin{aligned}
& F=\frac{D_{n}}{E T_{c}} \\
& E T_{c}=E T_{o} \cdot k_{c}
\end{aligned}
$$

where, $E T_{c}$ is crop evapotranspiration (mm/day), $E T_{o}$ is the reference evapotranspiration ( $\mathrm{mm} /$ day) and $k_{c}$ is the crop coefficient.

The operating time $t(\mathrm{~h})$ of each emitter during irrigation process was estimated using the following equation (Merriam and Keller, 1978) based on plant area $A\left(\mathrm{~m}^{2}\right)$, application efficiency $E a$ (decimal) and the emitter discharge $q(\ell / \mathrm{h})$.

$$
t=\frac{E T_{c} \times A \times F}{E a \times q}
$$

The water use efficiency (WUE) $\left(\mathrm{kg} / \mathrm{m}^{3}\right)$ as an indicator of effectiveness usage of irrigation water for increasing maize crop yield $Y(\mathrm{~kg} / \mathrm{fed})$, was 
calculated according to Bilalis $\boldsymbol{e t}$ al. (2009) using the following formula based on the total water applied $W\left(\mathrm{~m}^{3} / \mathrm{fed}\right)$ :

$$
W U E=\frac{Y}{W}
$$

\section{Cost Analysis}

Cost analysis was carried out by using the current prices for equipment and installation according to 2012 price level and maize production cost. The effect of emitter type on total cost and net return of maize production was then evaluated. The total cost per one feddan area is divided into: fixed costs and variable or operating costs. The estimated fixed costs were the depreciation, interest on investment, taxes and insurance costs. Meanwhile, the estimated variable costs were repair and maintenance, energy and the other costs. The following equations were used to calculate the cost analysis as shown in Table (3).

Table (3): Equation were used to calculate the cost analysis.

\begin{tabular}{|c|c|c|}
\hline Cost type & Equation & Parameters \\
\hline $\begin{array}{l}\text { Depreciation costs, } \\
D, \text { LE/fed/season }\end{array}$ & $D=\frac{P_{m}-S}{L_{m}}$ & $\begin{array}{l}\boldsymbol{P}_{\boldsymbol{m}} \text { : the cost new (LE), } \\
S \text { : salvage value price }\left(0.1 \mathrm{P}_{\mathrm{m}}\right)(\mathrm{LE}) . \boldsymbol{L}_{\boldsymbol{m}} \text { : } \\
\text { total expected life (year) }\end{array}$ \\
\hline $\begin{array}{l}\text { Interest on the } \\
\text { investment costs, } I \text {, } \\
\text { LE/fed/season }\end{array}$ & $I=\frac{P_{m}-S}{2} \times i$ & $\begin{array}{l}i \text { : interest rate as compounded annually } 10 \% \\
\text { (decimal) }\end{array}$ \\
\hline $\begin{array}{l}\text { Fixed costs, } F . C \\
\mathrm{LE} / \text { fed/season }\end{array}$ & $F . C=D+I+T_{i}$ & $\begin{array}{l}T_{i} \text { : taxes and insurance costs were assumed to } \\
\text { be } 1.5 \% \text { of the purchase price of the unit }\left(P_{m}\right)\end{array}$ \\
\hline $\begin{array}{l}\text { Repair, maintenance } \\
\text { costs, } R_{m}\end{array}$ & $R_{m}=(3 \%$ new $\cos t)$ & \\
\hline $\begin{array}{l}\text { Energy cost, } E . C, \\
\text { LE/fed/season }\end{array}$ & $\begin{array}{c}E . C=B p \times T \times P_{r} \\
B_{p}=\frac{Q \times T D H}{C \times E_{\text {overall }}}\end{array}$ & $\begin{array}{l}\boldsymbol{B}_{p}: \text { the brake power }(\mathrm{kW}), \\
T: \text { the annual operating time }(h r), \boldsymbol{P}_{r}: \text { cost of } \\
\text { electrical power }(0.125 \mathrm{LE} / \mathrm{kW}), \boldsymbol{Q}: \text { the total } \\
\text { discharge rate }(\ell / s), \\
T D \boldsymbol{H}: \text { the dynamic head }(\mathrm{m}) \\
\boldsymbol{C}: \text { the conversion coefficient }(\mathrm{C}=102) ; \\
\boldsymbol{E}_{\text {overall }}: \text { overall efficiency }(67.5 \% \text { for pump } \\
\text { derived by electric motor })\end{array}$ \\
\hline $\begin{array}{l}\text { Variable costs, V.C, } \\
\text { LE/fed/season }\end{array}$ & ${ }^{*} V . C=R_{m}+E . C+O$ & $\begin{array}{l}O: \text { the other costs (mechanization, maize } \\
\text { seeds, fertilization per feddan, pesticides, } \\
\text { labor, harvesting and transportation) }\end{array}$ \\
\hline $\begin{array}{l}\text { Total costs, } T . C \\
\mathrm{LE} / \mathrm{fed} / \mathrm{season}\end{array}$ & $T . C=F . C+V . C$ & \\
\hline $\begin{array}{l}\text { The economical net } \\
\text { seasonal income, } P \text {, } \\
\text { LE/fed }\end{array}$ & $P=\left(Y_{t} \times Y_{p}\right)-T . C$ & $\begin{array}{l}Y_{t}: \text { the total yield }(\mathrm{kg} / \mathrm{fed}) \\
Y_{d}: \text { the yield price }(\mathrm{LE} / \mathrm{kg}) ;\end{array}$ \\
\hline
\end{tabular}

"El-Awady et al., 1988, " Clark et al., 2007; ${ }^{* * * *}$ Younis et al., 1991 


\section{RESULTS AND DISCUSSION \\ Hydraulic Characteristics of Subunit}

The discharge versus operating pressure relationship plays a vital role in the characterization of emitters. It is one of the key factors in selecting an emitter type and system design. Table (4) shows the nominal and measured discharge, emitter discharge equation constants $(k, x)$, flow regime and the manufacturer's coefficient of variation $\left(C_{v}\right)$. Great differences between nominal and measured discharges were observed with emitter $\left(E m_{3}\right)$. The emitter exponent $x$ showed that its classification lies between pressure compensating and turbulent flow. The results indicated that the $C_{v}$ values classification of $E m_{1}, E m_{2}$ and $E m_{4}$ emitters were excellent, due to emitter the higher quality of these emitters than others. Meanwhile, $E m_{3}$ was classified poor and $E m_{5}$ was classified as marginal, maybe due to the lowest initial price.

Table (4): Average of discharge $(\ell / h)$, emitter constants $(k, x)$, flow regime and manufacturing coefficient of variation $\left(C_{v}\right)$ for emitters at $50 \mathrm{kPa}$.

\begin{tabular}{|c|c|c|c|c|c|c|}
\hline \multirow{2}{*}{ Emitter } & \multirow{2}{*}{$\begin{array}{l}\text { discharge } \\
" \ell / \mathrm{h} "\end{array}$} & \multicolumn{2}{|c|}{ constants } & \multirow{2}{*}{ Flow regime } & \multicolumn{2}{|r|}{ " $C_{v} "$} \\
\hline & & "k" & $" x "$ & & Value & Classi. $^{*}$ \\
\hline$E m_{1}$ & 4.23 & 2.52 & 0.12 & $\begin{array}{c}\text { Pressure } \\
\text { compensating } \\
\end{array}$ & 0.03 & Excellent \\
\hline$E m_{2}$ & 5.35 & 1.33 & 0.32 & $\begin{array}{l}\text { Partially pressure } \\
\text { compensating }\end{array}$ & 0.02 & Excellent \\
\hline$E m_{3}$ & 15.28 & 2.04 & 0.50 & Fully turbulent & 0.12 & Poor \\
\hline $\mathrm{Em}_{4}$ & 2.68 & 0.61 & 0.38 & $\begin{array}{c}\text { Partially } \\
\text { turbulent }\end{array}$ & 0.02 & Excellent \\
\hline $\mathrm{Em}_{5}$ & 86.0 & 7.82 & 0.63 & $\begin{array}{l}\text { Partially } \\
\text { turbulent }\end{array}$ & 0.10 & Marginal \\
\hline
\end{tabular}

"Classification of the manufacturing coefficient of variation

The uniformity plays an important role in water use efficiency (WUE). The coefficient of uniformity $(C U)$ of different lateral lengths indicated that the highest significant value of $C U$ was obtained at lateral length 15 $\mathrm{m}$ regardless the emitter type as shown in Table (5). Generally, water distribution uniformity was decreased by increasing lateral length with all emitters which agreed with (Ngigi, 2008). $C U$ values were significantly higher at lateral length of $30 \mathrm{~m}$ for $E m_{1}, E m_{2} ; E m_{4}$ and was good at lateral length of $15 \mathrm{~m}$ for $E m_{3} ; E m_{5}$. Maximum value of $C U$ was obtained with 
$E m_{4}$, meanwhile minimum value was obtained with $E m_{3}$. The results revealed that $C U$ was a variable relationship with emitter types, due to the differences in $C_{v}$ classifications, its found that $C U$ was increased by improvement $C_{v}$ classification agreed with (Amer, 2001 and Tagar, et al., 2010).

Table (5): Coefficient of uniformity $(C U)$ with different lateral lengths at operating pressure $50 \mathrm{kPa}$ for different emitters.

\begin{tabular}{|c|c|c|c|c|}
\hline \multirow{3}{*}{ Emitter type } & \multicolumn{4}{|c|}{ Coefficient of uniformity $(C U, \%)$} \\
\cline { 2 - 5 } & 15 & 20 & 25 & 30 \\
\cline { 2 - 5 } & $96.77^{\mathrm{ab}}$ & $96.57^{\mathrm{ab}}$ & $96.15^{\mathrm{ab}}$ & $95.49^{\mathrm{a}}$ \\
\hline$E m_{1}$ & $94.67^{\mathrm{b}}$ & $94.47^{\mathrm{b}}$ & $94.05^{\mathrm{b}}$ & $93.39^{\mathrm{a}}$ \\
\hline$E m_{2}$ & $81.69^{\mathrm{d}}$ & $79.80^{\mathrm{d}}$ & $75.04^{\mathrm{c}}$ & $70.21^{\mathrm{c}}$ \\
\hline$E m_{3}$ & $97.86^{\mathrm{a}}$ & $97.83^{\mathrm{a}}$ & $97.28^{\mathrm{a}}$ & $96.17^{\mathrm{a}}$ \\
\hline$E m_{4}$ & $90.18^{\mathrm{c}}$ & $84.29^{\mathrm{c}}$ & $77.44^{\mathrm{c}}$ & $75.82^{\mathrm{b}}$ \\
\hline$E m_{5}$ & &
\end{tabular}

Values with the same column with different superscript (a, b, c; d) are significantly different $(\mathrm{p}<0.05)$.

\section{Water Use Efficiency}

Generally, water use efficiency (WUE) is the ratio of grain yield to the total crop water use. The results indicated that $W U E$ were 1.47, 1.45, $1.30,1.29$ and $1.11 \mathrm{~kg} / \mathrm{m}^{3}$ for $E m_{4}, E m_{1}, E m_{5}, E m_{2}$ and $E m_{3}$ emitters, respectively as shown in Figure (2). It is clear from the obtained results that the highest value of $W U E$ was achieved at $E m_{4}$ emitter, which could be recommended for microirrigated maize in sandy soil. As shown in Table (5), the values of WUE increased by increasing the uniformity of different emitters except for $E m_{2}$ and $E m_{5}$. Although $C_{v}$ and $C U$ of $E m_{5}$ less than $E m_{2}$ but the WUE significantly increased with $E m_{5}$. This exception may be attributed to increasing crop cultivation intensity of $E m_{5}$ than $E m_{2}$ as a result of different discharges.

\section{Wetted Diameter}

The results showed that the overlap between emitters wetted diameter was increased the crop yield. Also, the wetted diameter (WD) was increased by increasing emitter discharge as shown in Figure (3) agreed with (Shan et al., 2011). Therefore, the highest value of $W D(100 \mathrm{~cm})$ was recorded with $E m_{5}$ and the lowest $(46 \mathrm{~cm})$ with $E m_{4}$. It clear that the wetted diameter overlap happened between emitters at the laterals, and no effect 
for examined lateral distances of all emitter types on overlap between its wetted diameter. So the lateral distance in the experiment didn't effect on the crop yield.

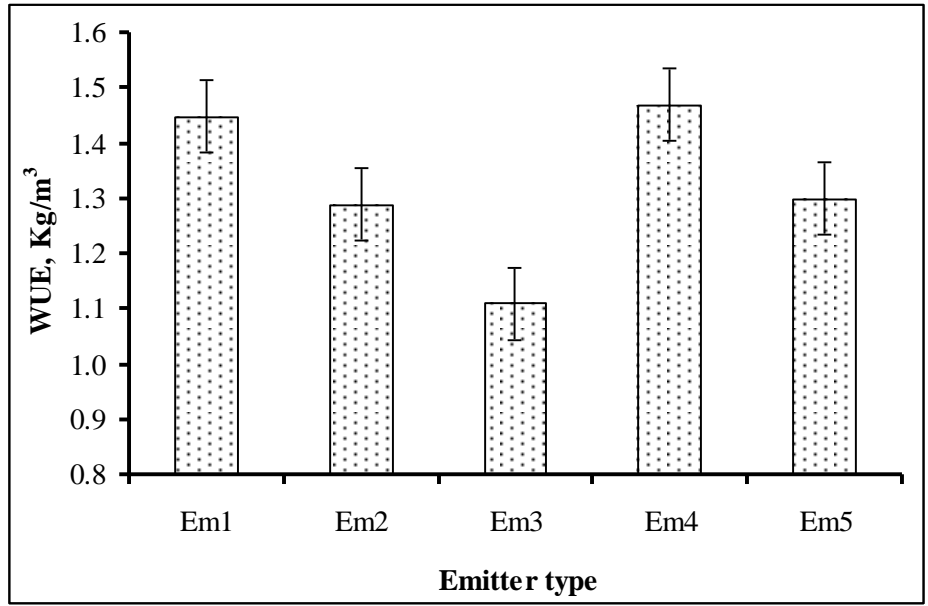

Figure (2): Water use efficiency (WUE) for emitter types.

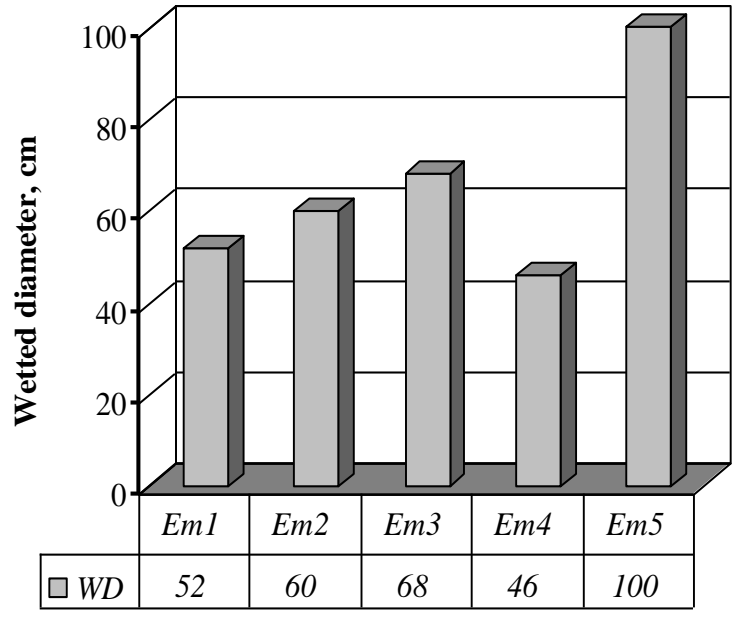

Emitter types

Figure (3): The relationship between emitter types and wetted diameter.

\section{Economic Return}

Table (6) shows the difference in fixed costs (depreciation, interest on investment; taxes and insurance costs) and operating or/variable costs (repair and maintenance, electrical energy costs and others) for each 
Table (6): The economic return of different emitters in 2012 year with inflation rate (Inf.) of 5 or $10 \%$.

\begin{tabular}{|c|c|c|c|c|c|c|c|c|c|c|c|c|c|c|c|}
\hline \multirow[b]{2}{*}{ Cost measures } & \multicolumn{3}{|c|}{$E m_{1}$} & \multicolumn{3}{|c|}{$E m_{2}$} & \multicolumn{3}{|c|}{$E m_{3}$} & \multicolumn{3}{|c|}{$\mathrm{Em}_{4}$} & \multicolumn{3}{|c|}{$E m_{5}$} \\
\hline & 2012 & $\begin{array}{l}\text { Inf. } \\
5 \%\end{array}$ & $\begin{array}{l}\text { Inf. } \\
10 \%\end{array}$ & 2012 & $\begin{array}{l}\text { Inf. } \\
5 \%\end{array}$ & $\begin{array}{l}\text { Inf. } \\
10 \%\end{array}$ & 2012 & $\begin{array}{l}\text { Inf. } \\
5 \%\end{array}$ & $\begin{array}{l}\text { Inf. } \\
10 \%\end{array}$ & 2012 & $\begin{array}{l}\text { Inf. } \\
5 \%\end{array}$ & $\begin{array}{l}\text { Inf. } \\
10 \%\end{array}$ & 2012 & $\begin{array}{l}\text { Inf. } \\
5 \%\end{array}$ & $\begin{array}{l}\text { Inf. } \\
10 \%\end{array}$ \\
\hline New network cost $(\mathbf{N})$ & 14679 & 15413 & 16147 & 11889 & 12484 & 13078 & 7406 & 7776 & 8147 & 10001 & 10501 & 11001 & 6161 & 6469 & 6777 \\
\hline 1. Fixed costs: & 1153 & 1194 & 1254 & 881 & 924 & 971 & 480 & 503 & 530 & 707 & 741 & 779 & 405 & 424 & 446 \\
\hline a) Depreciation & 885.3 & 928.8 & 974.8 & 676.0 & 709.1 & 744.6 & 352.3 & 369.2 & 388.6 & 534.4 & 560.4 & 588.9 & 298 & 312.2 & 328.3 \\
\hline b) Interest on investment & 232.6 & 230.8 & 242.7 & 178.3 & 186.9 & 196.7 & 111.1 & 116.3 & 122.7 & 150.0 & 157.2 & 165.5 & 93.2 & 96.7 & 101.9 \\
\hline c) Taxes and insurance & 34.9 & 34.6 & 36.4 & 26.8 & 28.0 & 29.5 & 16.7 & 17.4 & 18.4 & 22.5 & 23.6 & 24.8 & 14.0 & 14.5 & 15.3 \\
\hline 2. Variable costs: & 3429 & 3608 & 3790 & 3402 & 3578 & 3757 & 3361 & 3533 & 3708 & 3378 & 3552 & 3729 & 2509 & 2637 & 2767 \\
\hline a) Repair, maintenance & 146.8 & 161.8 & 177.6 & 118.9 & 131.1 & 143.9 & 74.1 & 81.7 & 89.6 & 100.0 & 110.3 & 121.0 & 61.6 & 67.9 & 74.6 \\
\hline b) Electrical energy & 36.82 & 38.66 & 42.53 & 37.81 & 39.70 & 43.67 & 42.06 & 44.16 & 48.58 & 32.92 & 34.57 & 38.02 & 11.96 & 12.56 & 13.81 \\
\hline c) Others & 3245 & 3407 & 3570 & 3245 & 3407 & 3570 & 3245 & 3407 & 3570 & 3245 & 3407 & 3570 & 2435 & 2557 & 2679 \\
\hline 3. Total cost $(1+2)$ & 4581 & 4802 & 5043 & 4283 & 4502 & 4728 & 3841 & 4036 & 4237 & 4085 & 4293 & 4508 & 2914 & 3061 & 3212 \\
\hline $\begin{array}{l}\text { 4. Applied water, } \\
\mathrm{m}^{3} / \mathrm{fed} / \text { season }\end{array}$ & 2800 & 2800 & 2800 & 2800 & 2800 & 2800 & 2800 & 2800 & 2800 & 2800 & 2800 & 2800 & 2800 & 2800 & 2800 \\
\hline 5. Yield production & 4058 & 4058 & 4058 & 3611 & 3611 & 3611 & 3095 & 3095 & 3095 & 4126 & 4126 & 4126 & 3652 & 3652 & 3652 \\
\hline $\begin{array}{l}\text { 6. Selling price, } \\
\mathrm{LE} / \mathrm{kg} / \text { season }\end{array}$ & 2.10 & 2.21 & 2.31 & 2.10 & 2.21 & 2.31 & 2.10 & 2.21 & 2.31 & 2.10 & 2.21 & 2.31 & 2.10 & 2.21 & 2.31 \\
\hline 7. Total return, $(5 x 6)$ & 8521 & 8947 & 9373 & 7582 & 7961 & 8340 & 6499 & 6824 & 7149 & 8665 & 9099 & 9532 & 7669 & 8052 & 8435 \\
\hline 8. NSI, (7-3) & 3939 & 4145 & 4329 & 3299 & 3459 & 3613 & 2658 & 2788 & 2911 & 4580 & 4805 & 5024 & 4755 & 4992 & 5223 \\
\hline 9. $R W U,(7 / 4)$ & 3.04 & 3.20 & 3.35 & 2.71 & 2.84 & 2.98 & 2.32 & 2.44 & 2.55 & 3.09 & 3.25 & 3.40 & 2.74 & 2.88 & 3.01 \\
\hline 10. $B C$ ratio, $(7 / 3)$ & 1.86 & 1.86 & 1.86 & 1.77 & 1.77 & 1.76 & 1.69 & 1.69 & 1.69 & 2.12 & 2.12 & 2.11 & 2.63 & 2.63 & 2.63 \\
\hline
\end{tabular}


operating conditions of emitters and lateral lengths. The electrical energy costs were estimated which had values of 36.82, 37.81, 42.06, 32.92 and $11.96 \mathrm{LE} / \mathrm{fed} / \mathrm{season}$ for $E m_{1}, E m_{2}, E m_{3}, E m_{4}$ and $E m_{5}$, respectively in 2012 year. The $E m_{5}$ provided the lowest electrical energy cost, due to the minimum operating hours.

$E m_{1}$ was recorded the highest total cost of $4581.40 \mathrm{LE} / \mathrm{fed} / \mathrm{season}$, since it was the highest initial price. Also, $E m_{5}$ was recorded the lowest total cost (2913.74 LE/fed/season) with highest net seasonal income (NSI) of 4755.02 LE/fed/season, due to relatively long internal distance between laterals and emitters, in addition to a low initial price of this emitter and the free irrigation water in Egypt. Meanwhile, the lowest net seasonal income was $E m_{3}$, although it has the lowest initial price, due to a low yield production as a result of a lowest $C_{v}$ and $C U$.

The highest return of water unit $(R W U)$ could be arranged in the following descending order $\left(E m_{4}>E m_{1}>E m_{5}>E m_{2}>E m_{3}\right)$ with values of $3.09,3.04,2.74,2.71$ and $2.32 \mathrm{LE} / \mathrm{m}^{3} /$ season, respectively. The seasonal benefit cost $(B C)$ ratio arranged in the following descending order $\left(E m_{5}>E m_{4}>E m_{1}>E m_{2}>E m_{3}\right)$ with values of 2.63, 2.12, 1.86, 1.77 and 1.69, respectively. Despite of $E m_{4}$ was the highest values of yield consequently $W U E$ and $R W U$, but $E m_{5}$ was the highest net seasonal income and $B C$ ratio, this may be due to it has a lowest total cost.

The suggested scenario for cost analysis takeing into account the effect of the changes in input and output prices of maize yield that maybe will occur in the next years, if inflation rate (Inf.) increases by 5 or $10 \%$. The net seasonal income $(N S I)$ and return of water unit $(R W U)$ were increased by the same ratio of inflation rate (Inf.) increasing. Although NSI and $R W U$ were increased by the same ratio of Inf. increasing, but $B C$ ratio remain in the same values.

\section{CONCLUSIONS}

Maize (Zea mays L.) is considered as one of the most important cereal crops in Egypt. The examined emitters divided into manufactured on-line $\left(E m_{1}, E m_{2} ; E m_{3}\right)$, in-line $\left(E m_{4}\right)$ and microtube $\left(E m_{5}\right)$ were evaluated with four lateral lengths $(15,20,25$ and $30 \mathrm{~m})$ at operating pressure of $50 \mathrm{kPa}$. 
The result showed that the $C U$ values was excellent at lateral length of 30 $\mathrm{m}$ for $E m_{1}, E m_{2} ; E m_{4}$ emitters and was good with lateral length of $15 \mathrm{~m}$ for $E m_{3} ; E m_{5}$ emitters. Water use efficiency (WUE) consequentially return of water unit $(R W U)$ is increased by increasing the uniformity of different emitters. The results indicated that the values of WUE and $R W U$ were $1.47 \mathrm{~kg} / \mathrm{m}^{3}$ and $3.09 \mathrm{LE} / \mathrm{m}^{3} /$ season for $E m_{4}$. $E m_{4}$ was the highest yield consequently $W U E$ and $R W U$, but $E m_{5}$ was the highest net seasonal income (NSI) and seasonal benefit cost $(B C)$ ratio, due to relatively long internal distance between laterals and emitters, in addition to a low initial price of this emitter. The suggested scenario for cost analysis take into account the effect of inflation rate increasing by 5 or $10 \%$. NSI and $R W U$ were increased by the same ratio of inflation rate increasing, but $B C$ ratio remain in the same values.

\section{REFERENCES}

Allen, R. G.; L. S. Pereira; R. Dirk and M. Smith (2011). Crop Evapotranspiration-Guidelines for computing crop water requirements. FAO Irrigation and Drainage Paper No. 56, 1998. Food and Agriculture Organization. Rome, Italy, PP: 83.

Amer, K. H. (2001). Comparison between modern irrigation system design. Unpublished Ph.D. Thesis of Agricultural Engineering, Department of Agricultural Engineering, Faculty of Agriculture, Minufiya University, Egypt, PP: 156.

ASABE EP 405.1 (2008). Design and installation of microirrigation Systems. ASABE, 1 - 5.

ASAE EP 458.0 (1999). Field evaluation of microirrigation systems. ASAE December 1999. ASAE. 792 - 797.

Black, T. A. (1969). The prediction of evaporation, drainage and soil water storage for a bare soil. Soil Sci. Soc. Amer. Proc. 33: 655 660 .

Christiansen, J. E. (1942). Irrigation by sprinkler. Bulletin 670 . California Agricultural Experiment Station. University of California. Berkeley, USA, PP: 124.

Clark, G. A.; D. Haman; J. F. Prochaska and M. Yitayew (2007). General System Design Principles. Agricultural Water 
Management, 95: 161 - 215.

Charles H. C.; B. W. Gerald; E. S. Barry; N. L. Alan and M. D. Richard (1999). Economics of drip irrigation for juice grape vineyards in New York State. Dept. of Agricultural Resource and Managerial Economics, College of Agriculture and Life Sciences, Cornell University, Ithaca, New York: 14853 - 7801.

El-Awady, M. M.; M. M. Moustafa; A. M. El-Gindy and M. A. ElGenaidy (1988). A trial on solar energy drying for agricultural products with simple setups. Misr Journal of Agricultural Engineering, 5(3): 377 - 392.

El-Sayed, E. I.; A. S. El-Sayed and H. H. Abdel-Maksoud (1994). A comparative study between two drip irrigation regimes under conditions of old lands in Egypt. Misr Journal of Agricultural Engineering, 11(1): 148-162.

FAO (2014). How to Feed the World in 2050. Food and Agriculture Organization of the United Nations, Rome, Italy, PP: 5.

Bilalis, D.; A. Karkanis; A. Efthimiadou; Ar. Konstantas and V. Triantafyllidis (2009). Effects of irrigation system and green manure on yield and nicotine content of Virginia (flue-cured) Organic tobacco (Nicotiana tabaccum), under Mediterranean conditions. Industrial Crops and Products, 29(2-3): 388 - 394.

Keller, J. and R. D. Bliesner (1990). Sprinkler and trickle irrigation. Van Nostrand, Reinhold, New York, PP: 643.

Keller, S. and P. Karmeli (1974). Trickle irrigation design parameters. Transaction of the ASAE, 17(4): 678 - 684.

Li, J.; W. Zhao; J. Yin; H. Zhang; Y. Li and J. Wen (2012). The effects of drip irrigation system uniformity on soil water and nitrogen distributions. Transactions of the ASABE, 55(2): 415 427.

Merriam, J. L. and J. Keller (1978). Farm Irrigation System Evaluation: A Guide for Management $3^{\text {rd }}$ ed. Logan, Utah: Agricultural and Irrigation Engineering Department, Utah State University, PP: 271. 
Ngigi, S. N. (2008). Technical evaluation and development of low-head drip irrigation systems in Kenya. Irrigation and Drainage. 57: 450 462.

Ragab, R. and C. Prudhomme (2002). Climate change and water resources management in arid and semi-arid regions-prospective and challenges for the $21^{\text {st }}$ century. Biosystms Engineering, 81(1): 3 - 34.

Shan, Y.; Q. Wang and C. Wang (2011). Simulated and measured soil wetting patterns for overlap zone under double points sources of drip irrigation. African Journal of Biotechnology, 10(63): 13744 13755.

Steel, R. G. and J. H. Torrie (1984). Principles and procedures of statistics. A biometric approach. $2^{\text {nd }}$ ed. McGraw Hill Book Co., New York, USA.

Tagar, A. A.; M. S. Mirjat; A. Soomro and A. Sarki (2010). Hydraulic performance of different emitters under varying lateral lengths. Journal of Agricultural Engineering, Vet. Sci., 26(2): 48 59.

Younis, S. M.; M. A. Shiboon and A. O. Aref (1991). Evaluation of some mechanical methods of rice production in Egypt. Misr Journal of Agricultural Engineering, 8(1): 39 - 49.

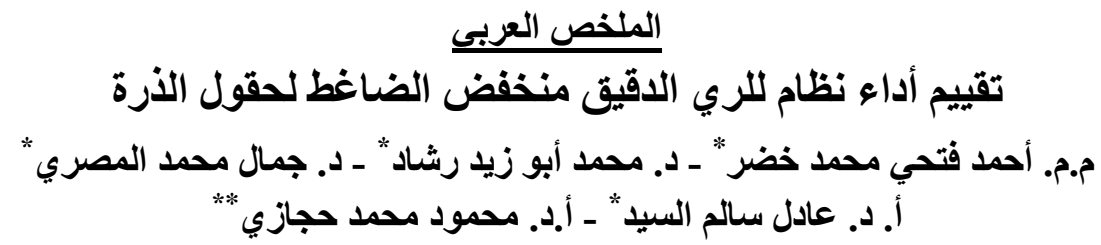

أجريت هذه الدراسة بالمعمل الهيدروليكي لقسم الهندة الزراعية ومزرعة كلية الزراعة،

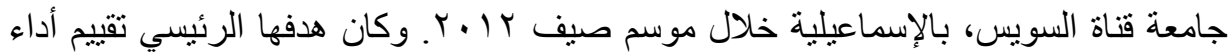

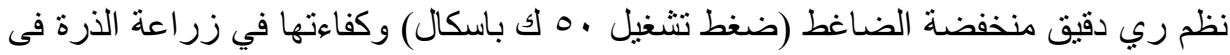

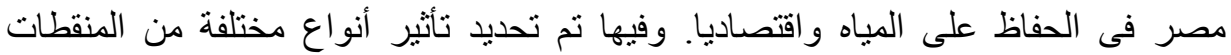

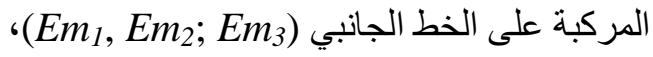

"مدرس مساعد، مدرس، أستاذ مساعد وأستاذ الهندسة الزراعية ـ قسم الهندسة الزراعية ـ كلية الزراعة - جامعة قناة السويس. "*:"أستاذ الهنسة الزراعية ـ قسم الهندسة الزراعية ـ كلية الزراعة ـ جامعة عين شمس. 
و المصنعة كوحدة واحدة مع الخط الجانبي (Em4) و الأنابيب الدقيقة المركبة على الخط الجانبي الجمأس

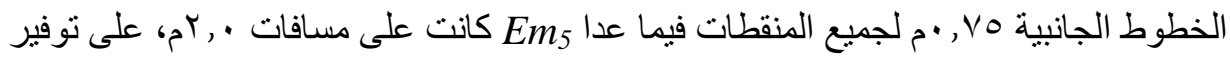

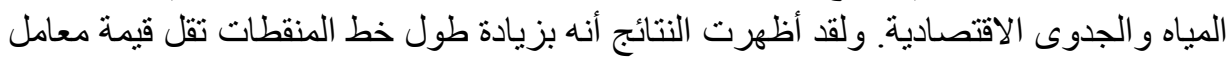

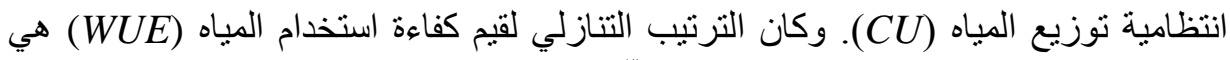

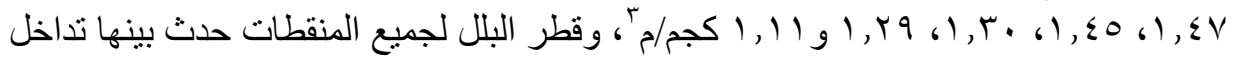

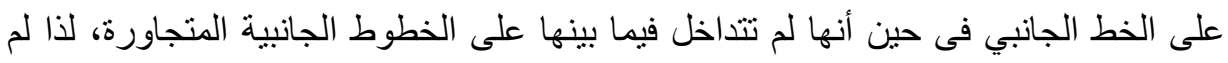

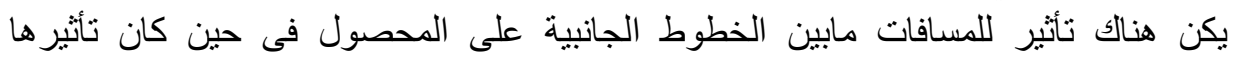

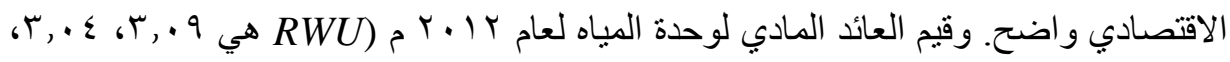

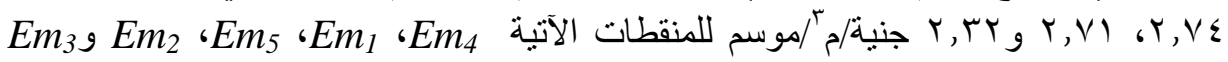

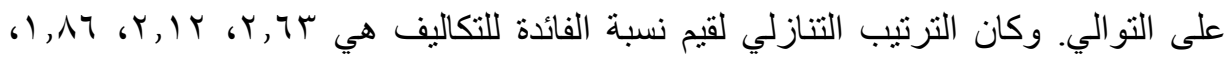

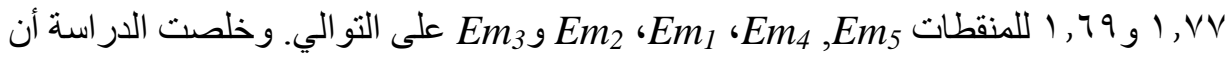
Em كان Em

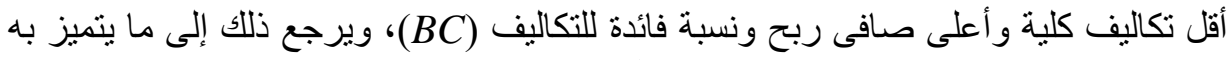

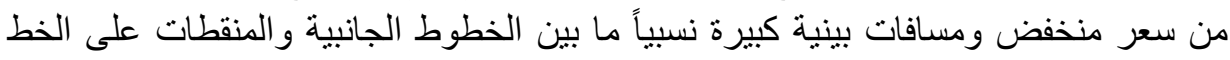

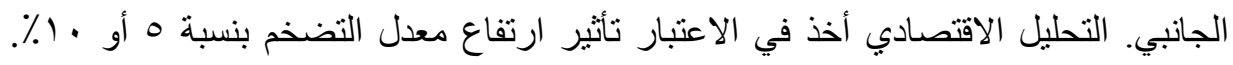

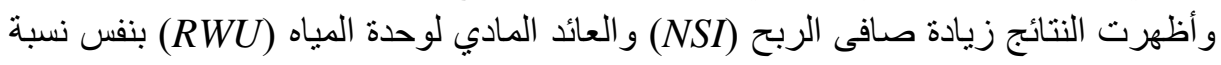

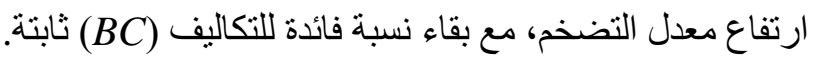

